\title{
Preparation of Animals with a High Degree of Chimerism by One-Step Coculture of Embryonic Stem Cells and Preimplantation Embryos
}

BioTechniques 22:544-549 (March 1997)

\author{
Jaspal S. Khillan and Yunhua \\ Bao \\ Thomas Jefferson University, \\ Philadelphia, PA, USA
}

\section{INTRODUCTION}

Targeting of genes by homologous recombination in pleuripotent embryonic stem $(\mathrm{ES})$ cells $(3,10)$ provides a powerful tool for introducing specific mutations in the genome of animals $(1,2,16)$. In general, a positive-negative selection gene-targeting cassette is prepared in which an exon of the target gene is interrupted by the gene for neomycin resistance $(5,9,12)$. A herpes simplex virus thymidine kinase (HSV TK) gene is fused at either one end or both ends of the genomic sequence as a negative selection marker. The targeting cassette is introduced into ES cells by electroporation, and the cells in which the endogenous gene is disrupted by homologous recombination are selected with G418 and gancyclovir or FIAU $(5,12)$.

The most common method for preparing chimeric animals is by direct microinjection of ES cells into the cavity of the blastocyst (1). Although this method is efficient, it has several limitations. First, it requires specialized training and skills. Second, it needs many expensive and sophisticated instruments. Third, the availability of healthy and well-expanded blastocysts is generally limited.

To fully realize the potential of gene knockout technology, a simple and efficient method is highly desirable. Based on the principle of aggregation of preimplantation embryos $(11,19,20)$, a coculture procedure of ES cells with early embryos (22) and a sandwich procedure $(13,14)$ were recently described to prepare animals with a high degree of chimerism.
In this report we describe a simple one-step coculture method to prepare highly chimeric animals reproducibly. The method does not involve special instruments or specialized skills, can be completed in a relatively short time and a large number of embryos can be manipulated simultaneously.

\section{MATERIALS AND METHODS}

\section{Isolation of Embryos}

Three- to five-week-old female FVB/N and C57BL/6 strains of mice, purchased from NIH FCRF (Frederick MD, USA), were superovulated with 5 IU of pregnant mare serum gonadotropin (PMSG) (Gestyl; Professional Compounding Centers of America, Houston, TX, USA), followed $48 \mathrm{~h}$ later by 5 IU of human chorionic gonadotropin (HCG) (Sigma Chemical, St. Louis, MO, USA), and the females were mated with males from the respective strain. The females were sacrificed 2.5 days postcoitus (p.c.), and 8to 16-cell embryos were collected by flushing the uterine horns with M16 medium (7) or Brinster's medium (Life Technologies, Gaithersburg, MD, USA). The embryos were stored in the same medium under paraffin oil in a $\mathrm{CO}_{2}$ incubator at $37^{\circ} \mathrm{C}$.

\section{Preparation of ES Cells}

Normal ES cells (R1 cells, a gift from Dr. A. Nagy [Mount Sinai Hospital, Toronto, Canada] and RW4 cells from Genome Systems [St. Louis, MO, USA]) or gene-targeted J1 ES cells with a null mutation in the gene for species. 
Table 1. Coculture of FVB/N Embryos with J1 ES Cells

\begin{tabular}{|cccccc|}
\hline $\begin{array}{c}\text { Experiment } \\
\text { \# }\end{array}$ & $\begin{array}{c}\text { No. of } \\
\text { Embryos }\end{array}$ & $\begin{array}{c}\text { No. of } \\
\text { Foster } \\
\text { Mothers }\end{array}$ & $\begin{array}{c}\text { No. } \\
\text { Pregnant }\end{array}$ & $\begin{array}{c}\text { Total No. } \\
\text { of Pups }\end{array}$ & $\begin{array}{c}\text { No. of } \\
\text { Chimeras }\end{array}$ \\
\hline I & 31 & 3 & 2 & 7 & $7(4)$ \\
II & 22 & 2 & 2 & 4 & $3(1)$ \\
III & 44 & 3 & 2 & 6 & $4(2)$ \\
Figures in parentheses represent the number of chimeras that were either dead \\
or killed by the foster mothers.
\end{tabular}

collagen type II (8), were used for coculture with embryos from the FVB/N and C57BL/6 strains of mice. The cells were cultured over the primary embryonic fibroblast feeders in $60-\mathrm{mm}$ petri dishes following published methods (16) in ES cell medium supplemented with 1000 IU of lymphocyte inhibitory factor (LIF) (Esgro; Life Technologies).

Confluent ES cell cultures were treated with $1 \mathrm{~mL}$ of $0.25 \%$ trypsin EDTA solution (Life Technologies) for 5-8 min at $37^{\circ} \mathrm{C}$ in a $\mathrm{CO}_{2}$ incubator, and the cells were harvested in $6 \mathrm{~mL}$ of ES cell medium. The cells were dispersed as single-cell suspensions by repeated pipetting, followed by centrifugation at $1000 \mathrm{rpm}$ (Model TJ-6 Centrifuge Rotor; Beckman Instruments, Fullerton, CA, USA) for $5 \mathrm{~min}$ at $4^{\circ} \mathrm{C}$. The cells were washed once in 5 $\mathrm{mL}$ of medium and resuspended in 5 $\mathrm{mL}$ of the same medium in a $50-\mathrm{mL}$ plastic tube. The tube was allowed to stand for $10 \mathrm{~min}$ to allow feeder layer cells to settle, after which the top $1 \mathrm{~mL}$ of the supernatant was transferred to a 1.5-mL microcentrifuge tube. The cells

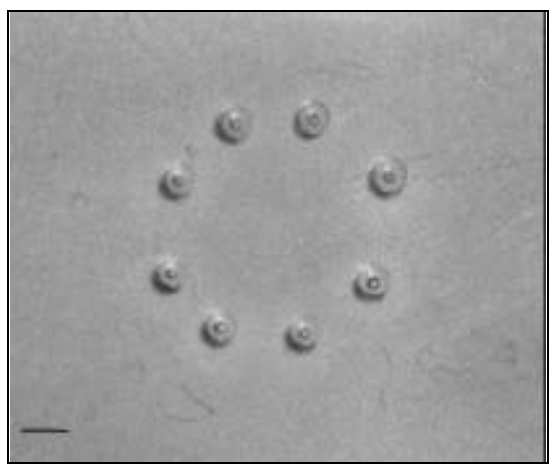

Figure 1. Microwells constructed on the surface of a 35- $\mathrm{mm}$ petri dish in a circle of about 0.5-cm diameter. The bar is equal to $1 \mathrm{~mm}$. were pelleted at $1000 \mathrm{rpm}$ in microcentrifuge tubes for $2 \mathrm{~min}$ at room temperature, followed by washing two times in $1 \mathrm{~mL}$ of medium A [M16 medium or Brinster's medium with $10 \mathrm{mg} / \mathrm{mL}$ final concentration of bovine serum albumin (BSA) (Pentex; Miles, Kankakee, IL, USA)]. The cells were resuspended in the same medium at a concentration of $1.5-2 \times 10^{5}$ cells $/ \mathrm{mL}$ and diluted, as necessary, with the same medium.

\section{Preparation of Coculture Dish}

To maximize contact between the ES cells and the embryos, 8-10 microwells, 0.3-0.5-mm outer diameter at the top and $0.1-0.2 \mathrm{~mm}$ at the bottom, were constructed in a $0.5-\mathrm{cm}$ circle on a $35-\mathrm{mm}$ petri dish. Figure 1 shows the top view of wells as seen under a stereomicroscope at $60 \times$ magnification. The microwells can be easily constructed by pressing the blunt end of a firepolished glass Pasteur pipet against the bottom of the petri dish (Genome Systems). Seventy microliters of ES cell suspension were layered over the microwells, and the cells were allowed to settle for $10 \mathrm{~min}$ at room temperature. The microwell dimensions accommodate 15-20 cells and also prevent adhesion between the embryos during coculture.

\section{Preparation of Zona-Free Morulae and Coculture with ES Cells}

About 30-50 healthy 8- to 16-cell morulae were collected in a minimum volume and transferred into a drop of $100 \mu \mathrm{L}$ acid Tyrode solution (137 mM $\mathrm{NaCl} ; 2.7 \mathrm{mM} \mathrm{KCl} ; 0.5 \mathrm{mM}$ $\mathrm{MgCl}_{2} \cdot 6 \mathrm{H}_{2} \mathrm{O} ; 5.6 \mathrm{mM}$ glucose; 1.6 $\mathrm{mM} \mathrm{CaCl} 2 \cdot 2 \mathrm{H}_{2} \mathrm{O}$ and $0.4 \%$ polyvinylpyrrolidine, pH 2.5) (7) in a 60-mm 


\section{Research Reports}

petri dish. Up to 100 embryos can be processed easily in the same volume. The embryos were monitored constantly under a stereomicroscope. Once the zona pellucida was dissolved, the solution was diluted with $1 \mathrm{~mL}$ of medium A to minimize exposure of the embryos to acidic $\mathrm{pH}$, followed by washing in 5-7 mL of fresh medium. A high concentration of BSA $(10 \mathrm{mg} / \mathrm{mL})$ in medium A prevented adhesion of the denuded embryos with each other during subsequent handling before coculture (see Results). One embryo was then transferred to each microwell carrying the ES cells and incubated overnight in a $\mathrm{CO}_{2}$ incubator at $37^{\circ} \mathrm{C}$.

\section{Preparation of Chimeric Animals}

After overnight culture, blastocysts were collected from the wells and washed in $5 \mathrm{~mL}$ of medium A. Approximately 8-10 embryos were surgically transferred into one uterine horn of 6-8-week-old, 2.5-day p.c. pseudopregnant CD1 female mice. The newborn pups were screened for mutation in the type II collagen gene by the polymerase chain reaction (PCR) or for chimerism (based on coat color). Chimeric animals were bred with nor-

Table 2. Coculture of R1 ES Cells with FVB/N and C57BL/6 Embryos

\begin{tabular}{|ccccccc|}
\hline $\begin{array}{c}\text { Experiment } \\
\#\end{array}$ & $\begin{array}{c}\text { Mouse } \\
\text { Strain }\end{array}$ & $\begin{array}{c}\text { No. of } \\
\text { Embryos }\end{array}$ & $\begin{array}{c}\text { No. of } \\
\text { Foster } \\
\text { Mothers }\end{array}$ & $\begin{array}{c}\text { No. } \\
\text { Pregnant }\end{array}$ & $\begin{array}{c}\text { Total No. } \\
\text { of Pups }\end{array}$ & $\begin{array}{c}\text { No. of } \\
\text { Chimeras }\end{array}$ \\
\hline I & FVB/N & 26 & 3 & 1 & 3 & 1 \\
II & FVB/N & 33 & 3 & 2 & 5 & 5 \\
III & C57BL/6 & 29 & 3 & 3 & $12^{\text {a }}$ & $6^{\text {b }}$ \\
aSix pups were either cannibalized or killed by the mothers. Two pups had very \\
pale skin indicating a high contribution of ES cells. \\
bTwo pups were larger in size, displayed high chimerism and died shortly after \\
birth. Four animals that survived to adulthood were $>90 \%$ chimeric by coat color. \\
\hline
\end{tabular}

mal animals of the same strain from which the embryos were isolated, and the F1 progeny were analyzed for germ-line transmission of the mutant allele of type II collagen by PCR (8).

\section{RESULTS}

\section{Removal of the Zona Pellucida}

To allow successful integration of ES cells into the embryo, the zona pellucida was removed by treating the embryos with acid Tyrode solution (7). Since Tyrode solution has an acidic $\mathrm{pH}$ of 2.5, a short duration is critical for embryo survival. Approximately 90\%-

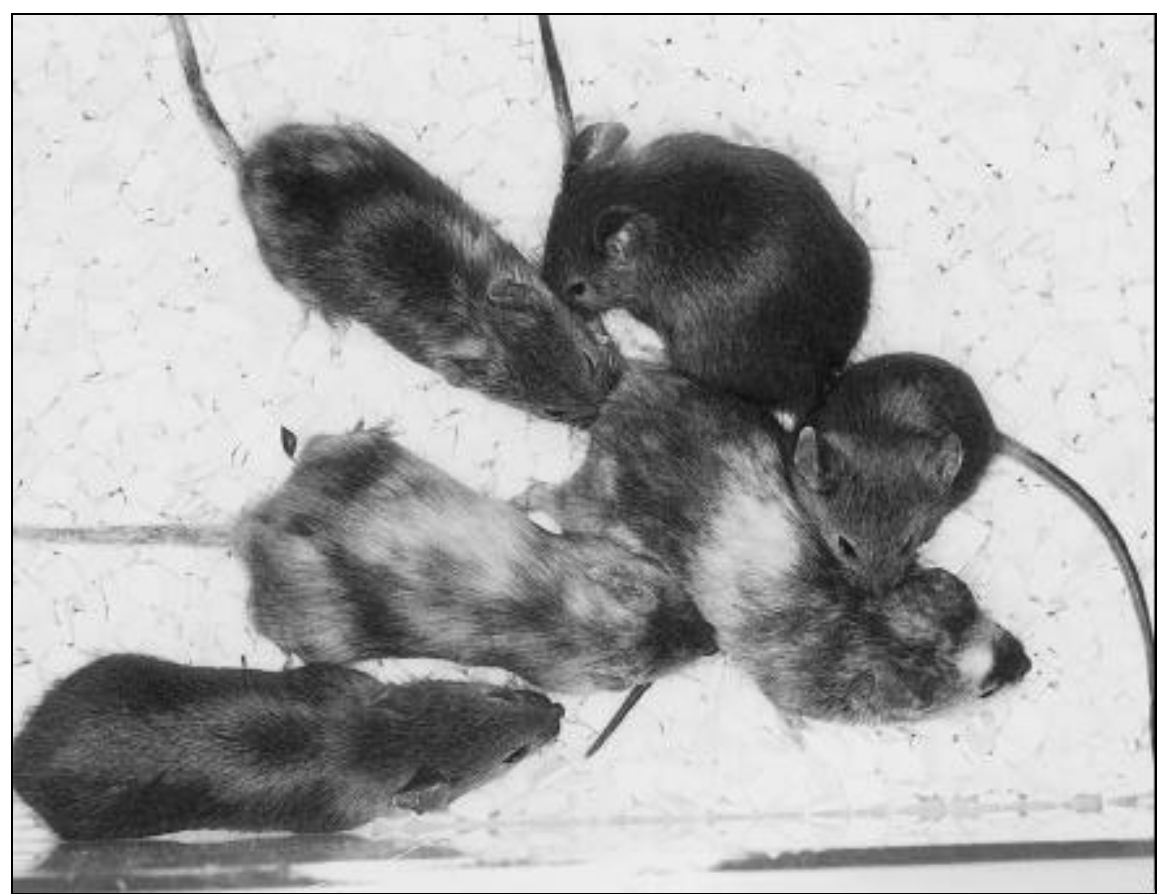

Figure 2. Chimeric animals prepared from coculture of FVB/N embryos (albino) with J1 cells derived from 129Sv (agouti) strain of mice. Three chimeras displayed almost complete ES cell-derived phenotype, whereas the other three were between $70 \%$ and $90 \%$ chimeric.
95\% of the embryos developed to healthy appearing blastocysts when the treatment was kept shorter than 40-50 s. Survival decreased to about $20 \%$ when exposure was longer than $90 \mathrm{~s}$ (data not shown). Therefore, the embryos were monitored constantly under a stereomicroscope during the treatment to prevent prolonged exposure to acidic pH.

\section{Viability of Cultured Embryos}

Previously, Wood et al. (22) observed that long-term culture of embryos over the bed of ES cells is detrimental to their survival. To determine whether a high protein concentration would prevent adhesion of zona-free embryos with each other during handling and allow maximum survival of the embryos after coculture, embryo manipulations were performed in Brinster's medium with different concentrations of BSA. Only a minimal amount of adhesion between the embryos occurred when $10 \mathrm{mg} / \mathrm{mL}$ BSA were added to the culture medium, and approximately $90 \%-95 \%$ of the embryos developed into blastocysts. Most ES cells appeared to integrate with the embryos after overnight culture, and no sign of cell death inside or outside the microwell was noticed under these conditions. Small aggregates of ES cells attached to the embryos were occasionally seen that also integrated with the embryos following extended cultures.

\section{Contribution of ES Cells to Neonates}

Data presented in Table 1 show the results of three independent experiments on coculture of gene-targeted $\mathrm{J} 1$ cells with inbred FVB/N embryos 
Table 3. Coculture of C57BL/6 Embryos with RW4 ES Cells

\begin{tabular}{|cccccc|}
\hline $\begin{array}{c}\text { Experiment } \\
\text { \# }\end{array}$ & $\begin{array}{c}\text { No. of } \\
\text { Embryos }\end{array}$ & $\begin{array}{c}\text { No. of } \\
\text { Foster } \\
\text { Mothers }\end{array}$ & $\begin{array}{c}\text { No. } \\
\text { Pregnant }\end{array}$ & $\begin{array}{c}\text { Total No. } \\
\text { of Pups }\end{array}$ & $\begin{array}{c}\text { No. of } \\
\text { Chimeras }\end{array}$ \\
\hline I & 28 & 3 & 3 & 10 & 8 \\
II & 11 & 1 & 1 & 4 & 4 \\
III & 21 & 3 & 3 & 9 & 6 \\
\hline
\end{tabular}

Table 4. Germ-line Transmission of Chimeric Animals

\begin{tabular}{|cccc|}
\hline Experiment \# & No. Tested & Sex & No. Transmitted \\
\hline I & 3 & $M$ & 3 \\
II & $2^{\mathrm{a}}$ & $\mathrm{M}$ & 1 \\
III & $2^{\mathrm{b}}$ & $\mathrm{M}$ & 1 \\
aThe animal that did not transmit the gene was $<50 \%$ chimeric. \\
bOne chimeric animal that displayed almost $100 \%$ contribution of ES cells was \\
sterile.
\end{tabular}

(albino coat color). A total of 97 embryos were implanted into 8 recipient mothers. Six of the recipients delivered 17 pups, of which 14 pups $(83 \%)$ were chimeric for the ES cells. Twelve chimeric animals displayed more than $70 \%-80 \%$ contribution of ES cells, as observed by the coat color. From seven chimeras that survived to adulthood, three were almost indistinguishable from the agouti $129 \mathrm{~Sv}$ strain of mice from which the $\mathrm{J} 1$ cell line was derived, suggesting complete derivation from ES cells (Figure 2). Similarly, the coculture of $59 \mathrm{FVB} / \mathrm{N}$ embryos with R1 cells produced 8 pups, of which 6 pups were over $75 \%$ chimeric by coat color (Table 2: Experiments I and II).

A high degree of chimerism in the newborns was also observed when R1 cells were cultured with C57BL/6 embryos. Of the 29 embryos that were implanted into three recipient mothers, a total of 12 pups were born (Table 2: Experiment III). Six of these pups were over $90 \%$ chimeric. The other six were cannibalized by the mothers before testing. However, the carcasses from two of the cannibalized pups had light pale skin, indicating a high contribution of ES cells.

To further test the efficacy of this method, C57BL/6 embryos were cultured with RW4 ES cells, a cell line derived from the $129 \mathrm{SvJ}$ strain of mice with chinchilla background. As shown in Table 3, a total of 23 pups were born from 60 embryos in three separate experiments. Eighteen pups (80\%) displayed more than $90 \%$ contribution of RW4 cells, determined by the color of the skin and pink eye pigmentation in contrast to black pigmentation of the host embryos. About $50 \%$ of these chimeras had open eyelids and were cannibalized by the mothers. Two of the surviving pups displayed almost complete RW4 ES cell contribution, with chinchilla coat color, whereas a third pup showed only about 50\% contribution, with large, white patches on a black background (not shown).

\section{Germ-Line Transmission of ES Cell Markers}

Chimeric animals prepared from the coculture of ES cells with a targeted mutation in collagen type II were crossed with normal FVB/N animals, and the progeny were examined by PCR or by Southern blot analysis using ${ }^{32} \mathrm{P}$-labeled probes for the collagen type II gene (8). All the fertile chimeras that displayed more than $75 \%$ chimerism transmitted the mutant allele to their progeny (Table 4). One chimera that displayed almost $100 \%$ contribution of ES cells was sterile and did not produce any progeny. However, the other two high-degree chimeras transmitted ES cell markers to almost $100 \%$ of their progeny, suggesting a complete derivation of the germ line in these animals from ES cells. 


\section{DISCUSSION}

Gene knockout by means of homologous recombination in ES cells is a powerful system to unravel the function of genes that control development and differentiation in the organism. Techniques that are simple, efficient and reproducible can therefore expedite the process for functional analysis of specific genes.

The method described here is highly reproducible and is based on the hypothesis that ES cells establish an axis of integration into the embryo (Figure 3 ). In the method described by Wood et al. (22), embryos are cultured over a bed of ES cells, and the embryos with adherent ES cells are subsequently collected and transferred into another petri dish. This requires certain manipulations before there is complete integration of ES cells into the embryos. The microwells in the present procedure provide a physical axis for efficient integration of ES cells into the embryos.

This concept is supported by the

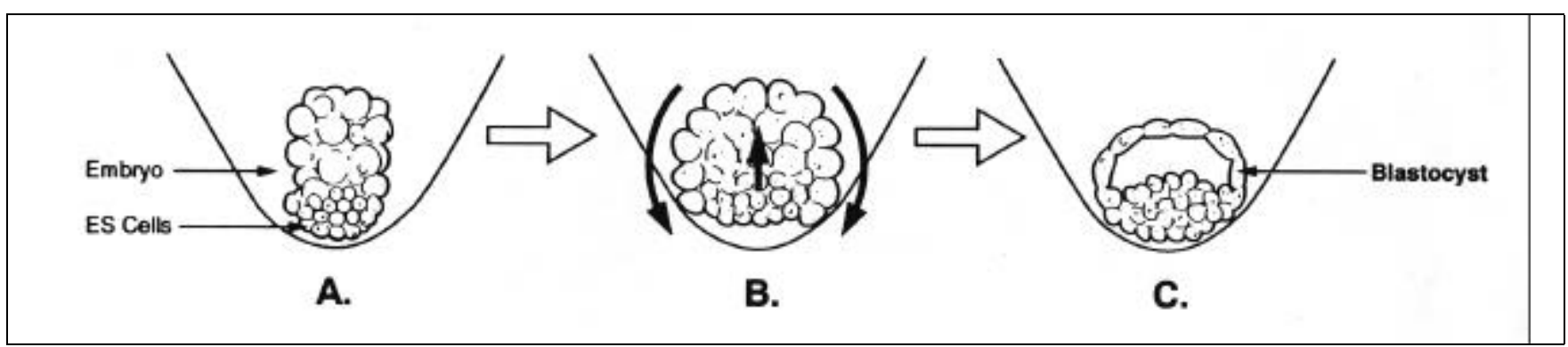

Figure 3. Model for the integration of ES cells into a morula. (A) The bottom of the microwell provides an area for tight cell-cell contact and simulates the formation of ES cell aggregates described in previous methods $(13,14,22)$. (B) Transfer of embryos over these cells establishes cell-cell-embryo contact. As the cells of the embryo continue to divide and move around the ES cells (downward arrows), an axis of ES cell integration is established (upward arrow). (C) Further growth of the embryo therefore results in internalization of ES cells into the embryo. 
hypotheses proposed by other investigators for the development of preimplantation embryos $(6,20,23,24)$. In preimplantation embryos, the apolar cells on the inner side of morulae are directed to differentiate into the inner cell mass, whereas the outer polar cells are directed to form the trophectoderm (TE). Therefore, the ES cells in our microwell coculture procedure may localize to the inside of the embryo and contribute predominately to the inner cell mass, whereas the cells from the morula that are on the outside contribute to the formation of TE. It is also possible that ES cells may induce embryonic cells to form TE.

In contrast to previous observations (22), $90 \%-95 \%$ of our embryos survived consistently, and animals with more than $90 \%$ chimerism could be generated reproducibly even after overnight culture of embryos with ES cells. This may be attributed to the following: (i) a low concentration of ES cells used for the coculture; (ii) a simple medium that is known to be conducive to the growth of preimplantation embryos (7); and (iii) a small number of ES cells in microwells, which may prevent the overgrowth and abnormal development of the embryo. The breeding of chimeric animals with normal animals revealed that most of the animals with high chimerism were fertile and capable of germ-line transmission.

The microwells described in this procedure can be constructed by simple tools available in any laboratory. The data obtained with two different strains of mice and three independent ES cell lines suggest that the method may be also applicable to other strains of mice and ES cell lines. It may also be an alternative to microinjection of DNA into zygotes (15) to identify novel genes and their regulatory sequences with the gene trap or promoter trap vectors $(4,17)$ or to create transgenic animals for large animal species in which the availability of zygotes is generally limited and the ES cell lines have been established (18,21).

\section{ACKNOWLEDGMENTS}

We thank Dr. Darwin J. Prockop for his interest in these studies. We ac- knowledge valuable discussions with Drs. Heiner Westphal, Eric Lee and Mrs. S.P. Huang at NIH. We thank Drs. Thomas Knudsen, Devjani Chatterjee and Gerald Grunwald for critically reading the manuscript.

This work was supported in part by grants from the Lucille P. Markey Foundation and the National Institutes of Health (AR39740).

\section{REFERENCES}

1.Bradley, A., M. Evans, M.H. Kaufman and E. Robertson. 1984. Formation of germ-line chimaeras from embryo-derived teratocarcinoma cell lines. Nature 309:255-256.

2.Capecchi, M.R. 1989. The new mouse genetics: altering the genome by gene targeting. Trends Genet. 5:70-76.

3.Evans, M.J. and M.H. Kaufman. 1981. Establishment in culture of pluripotential cells from mouse embryos. Nature 292:154-156.

4.Friedrich, G. and P. Soriano. 1991. Promoter traps in embryonic stem cells: a genetic screen to identify and mutate developmental genes in mice. Genes Dev. 5:1513-1523.

5.Hasty, P., M. Crist, M. Grompe and A. Bradley. 1994. Efficiency of insertion versus replacement vector targeting varies at different chromosomal loci. Mol. Cell. Biol 14:8385-8390.

6.Hillman, N., M. Sherman and C.F. Graham. 1972. The effect of spatial arrangement on cell determination during mouse development. J. Embryol. Exp. Morphol. 28:263-278.

7.Hogan, B., F. Costantini and E. Lacy. 1986. Manipulating the Mouse Embryo. Cold Spring Harbor Laboratory, Cold Spring Harbor, NY.

8.Li, S-W., D.J. Prockop, H. Helminen, R. Fassler, T. Lepvetelainen, K. Kiraly, A. Peltari, J. Arokoski, H. Lui, M. Arita and J.S. Khillan. 1995. Transgenic mice with targeted inactivation of the Col2aI gene for collagen II develop a skeleton with membranous and periosteal bone but no endochondral bone. Genes Dev. 9:2821-2830.

9.Mansour, S.L., K.R. Thomas and M.R. Capecchi. 1988. Disruption of the protooncogene int-2 in mouse embryo-derived stem cells: a general strategy for targeting mutations to non-selectable genes. Nature 336:348352.

10.Martin, G.R. 1981. Isolation of a pleuripotent cell line from early mouse embryos cultured in medium conditioned by teratocarcinoma stem cells. Proc. Natl. Acad. Sci. USA 78:7634-7638.

11.Mintz, B. 1965. Experimental genetic mosaicism in mouse, p. 194-207. In C.E.W. Wolstenholme and M. O'Conner (Eds.), Preimplantation Stages of Pregnancy. CIBA Foundation Symposium, London.

12.Mortensen, R. 1993. Overview of gene targeting by homologous recombination, $\mathrm{p}$. 9.15.1-9.17.3. In F.M. Ausubel et al. (Eds.), Current Protocols in Molecular Biology, Vol. 1. John Wiley and Sons, New York.
13.Nagy, A., E. Gocza, E.M. Diaz, V.R. Prideaux, E. Ivanyi, M. Markkula and J. Rossant. 1990. Embryonic stem cells alone are able to support fetal development in the mouse. Development 110:815-821.

14.Nagy, A., J. Rossant, R. Nagy, W. Abramow-Newerly and J.C. Roder. 1993. Derivation of completely cell culture-derived mice from early-passage embryonic stem cells. Proc. Natl. Acad. Sci. USA 90:8424-8428.

15.Palmiter, R.D. and R.L. Brinster. 1986. Germ-line transformation of mice. Annu. Rev. Genet. 20:465-499.

16.Robertson, E.J. 1987. Embryo-derived stem cell lines, p. 71-112. In E.J. Robertson (Ed.), Teratocarcinomas and Embryonic Stem Cells: A Practical Approach. IRL Press, Oxford.

17.Rossant, J. and N. Hopkins. 1992. Of fin and fur: mutational analysis of vertebrate embryonic development. Genes Dev. 6:1-13.

18.Sims, M. and N.L. First. 1994. Production of calves by transfer of nuclei from cultured inner cell mass cells. Proc. Natl. Acad. Sci. USA 91:6143-6147.

19.Tarkowski, A.K. 1961 Mouse chimaeras developed from fused eggs. Nature 190:857860.

20.Tarkowski, A.K. and J. Wroblewska. 1987. Development of blastomeres of mouse eggs isolated at 4- and 8-cell stage. J. Embryol. Exp. Morphol. 18:155-180.

21.Thomson, J.A., J. Kalishman, T.G. Golos, M. Durning, C.P. Harris, R.A. Becker and J.P. Hearn. 1995. Isolation of primate embryonic stem cells. Proc. Natl. Acad. Sci. USA 92:7844-7848.

22.Wood, S.A., W.S. Pascoe, C. Schmidt, R. Kemler, M.J. Evans and N.D. Allen. 1993. Simple and efficient production of embryonic stem cell-embryo chimeras by coculture. Proc. Natl. Acad. Sci. USA 90:4582-4585.

23.Ziomek, C.A. and M.H. Johnson. 1982. Cell populations in the late morula and early blastocyst of the mouse. Dev. Biol. 91:431-439.

24.Ziomek, C.A. and M.H. Johnson. 1982. The roles of phenotype and position in guiding the fate of 16-cell mouse blastomeres. Dev. Biol. 91:440-447.

Received 4 March 1996; accepted 13 September 1996.

Address correspondence to:

Jaspal S. Khillan

Bluemle Life Science Bldg., Rm. 310

Department of Biochemistry and Molecular Biology

Jefferson Institute of Molecular Medicine

Thomas Jefferson University

Philadelphia, PA 19107, USA

Internet:J_khillan@lac.jci.tju.edu 